\title{
Nursing appointment and cardiometabolic control of diabetics: a randomized clinical trial
}

\author{
Consulta de enfermagem e controle cardiometabólico de diabéticos: ensaio clínico randomizado
}

La consulta de enfermería y el control cardiometabólico de diabéticos: ensayo clínico aleatorizado

\section{Elen Ferraz Teston', Guilherme de Oliveira de Arruda", Catarina Aparecida Sales", Deise Serafim", Sonia Silva Marcon"}

\author{
' Universidade Estadual do Paraná, Nursing Department. Paranavaí, Paraná, Brazil. \\ "Universidade Estadual de Maringá, Postgraduate Program in Nursing. Maringá, Paraná, Brazil.
}

How to cite this article:

Teston EF, Arruda GO, Sales CA, Marcon SS. Nursing appointment and cardiometabolic control of diabetics: a randomized clinical trial. Rev Bras Enferm [Internet]. 2017;70(3):468-74. DOI: http://dx.doi.org/10.1590/0034-7167-2016-0352

Submission: 06-25-2016 Approval: 09-01-2016

\begin{abstract}
Objective: to verify the effect of nursing appointment on cardiometabolic profile of people with Diabetes Mellitus type 2. Method: randomized controlled trial, developed with 134 individuals chosen for two groups: intervention and control. The intervention consisted of three nursing appointments alternated bimonthly, with two phone calls, over five months. The control group received usual care offered by the Health Unit. Data were collected through semi-structured interviews before and after the intervention, in addition to conducting laboratory tests. Results: after the intervention, a significant difference was shown in the amount of glycated hemoglobin $(p=0.006)$ and in the systolic blood pressure $(p=0.031)$, which were higher in the control group. Conclusion: besides being low-cost and easy to develop on the monitoring routine of people with diabetes, the intervention performed influenced positively the biochemical profile.
\end{abstract}

Descriptors: Diabetes Mellitus; Nursing; Self-Care. Chronic Disease; Clinical Trial.

\section{RESUMO}

Objetivo: verificar o efeito da consulta de enfermagem sobre o perfil cardiometabólico de pessoas com Diabetes Mellitus tipo 2. Método: ensaio clínico controlado e randomizado, desenvolvido com 134 indivíduos sorteados para dois grupos: intervenção e controle. A intervenção consistiu em três consultas de enfermagem bimensais alternadas, com duas ligações telefônicas, ao longo de cinco meses. O grupo-controle recebeu os cuidados habituais oferecidos pela Unidade de Saúde. Os dados foram coletados mediante entrevistas semiestruturadas antes e após a intervenção, além da realização de exames laboratoriais. Resultados: após a intervenção, foi evidenciada diferença significativa no valor da hemoglobina glicada $(p=0,006)$ e da pressão arterial sistólica ( $p=0,031)$, que se mostraram mais elevadas no grupo-controle. Conclusão: a intervenção realizada, além de ser de baixo custo e de fácil desenvolvimento na rotina de acompanhamento da pessoa com diabetes, influenciou positivamente a melhora do perfil bioquímico.

Descritores: Diabetes Mellitus; Enfermagem; Autocuidado. Doença Crônica; Ensaio Clínico.

\section{RESUMEN}

Objetivo: comprobar el resultado de la consulta de enfermería sobre el perfil cardiometabólico en personas con Diabetes mellitus tipo 2. Método: ensayo clínico controlado y aleatorizado, en el cual participaron 134 sujetos. Se los dividieron de forma aleatoria en dos grupos: intervención y control. La intervención consistió en tres consultas de enfermería cada dos meses alternados, con dos Ilamadas, a lo largo de cinco meses. El grupo control recibió los cuidados usuales de la Unidad de Salud. Se recolectaron los datos a través de entrevistas semiestructuradas, antes y después de la intervención, y de análisis de laboratorio. Resultados: después de la intervención, se observaron diferencias significativas en el valor de la hemoglobina glicosilada $(p=0,006)$ y de la presión arterial sistólica ( $p=0,031)$, que fueron más elevados en el grupo control. Conclusión: la intervención realizada, por ser de bajo costo y de fácil manejo en el acompañamiento de la persona con diabetes, influyó positivamente en la mejora del perfil bioquímico.

Descriptores: Diabetes Mellitus; Enfermería; Autocuidado. Enfermedad Crónica; Ensayo Clínico.

\section{CORRESPONDING AUTHOR}

Elen Ferraz Teston

E-mail: elen-1208@hotmail.com 


\section{INTRODUCTION}

Diabetes Mellitus type 2 (DM2) is a disease with increasing incidence and worldwide prevalence of $8.3 \%^{(1)}$. Brazil is the fifth country in number of cases of DM2, with approximately $7,600,000$ people affected ${ }^{(1)}$ and $6.2 \%$ self-reported prevalence for adults ${ }^{(2)}$. If not controlled, this disease can lead to complications that, besides occasioning disabilities, it negatively influences quality of life and increases annual health care expenses ${ }^{(1)}$, being the cause of $5.3 \%$ of all deaths registered in Brazil $^{(3)}$.

Glycemic rate combined with inadequate lipid levels and blood pressure decompensation are the most involved variables in the etiology of DM2 acute and chronic complications. Although the control of these rates is essential to reduce the consequences of the disease in medium and long terms ${ }^{(4)}$, national data show that relative frequency of individuals with DM2 that present a satisfactory control of glycated hemoglobin (HbA1c) is only $27 \%{ }^{(5)}$.

The individual's behavior regarding the disease, therefore, must be the main focus of assistance, since inadequate habits of life and presence of comorbidities are among the factors that most affect glycemic decontrol ${ }^{(6)}$. Thus, over time, people with a chronic disease tend to abandon behavioral changes that are important to control the disease, which constitutes a challenge for health care planning ${ }^{(7)}$.

To overcome such challenges, intervention studies have been conducted with people with DM, which involves telephone monitoring ${ }^{(8)}$, use of text messages ${ }^{(9)}$, and home visit ${ }^{(10)}$, and their results showed, in addition to a significant reduction in $\mathrm{HbA} 1 \mathrm{c}$ levels, a possible positive influence on identifying barriers to self-care, on increasing knowledge about the disease, and on acquisition of healthy habits ${ }^{(9-10)}$, also favoring glycemic $^{(8-10)}$, lipid ${ }^{(8-9)}$ and blood pressure ${ }^{(9)}$ controls.

Most interventions were applied in a collective way, covering groups of people with DM. However, individual interventions with an emphasis on behavior change can generate best clinical results and quality of life, according to a study conducted in Denmark with 143 people with DM2 $2^{(11)}$.

According to what has been stated, nursing appointment is considered an opportunity for nurses to act effectively on empowerment for self-care and for the healthcare improvement of DM patients, since it is significantly associated with glycemic control ${ }^{(8,12,13)}$. However, this activity is not implemented routinely in health services, as only actions related to history and evolution of nursing predominate ${ }^{(14)}$.

A study conducted with 150 individuals with DM2, linked to a private health plan in a municipality in the North of Paraná State, showed that individual intervention consisting of two halfyearly nursing appointments intercalated by a telephone contact, resulted in significant positive effects on knowledge and quality of life and no significant positive effect on self-care ${ }^{(13)}$.

The profile of population with diabetes, marked by glycemic decontrol, originates from differences in the attention given by the health system to people in chronic conditions, as well as demands and health status of this population ${ }^{(6)}$. This indicates the need for nursing interventions that promote empowerment of people with DM2, in such a way that they can handle their own treatment and clinical management, reducing dependence on professional support and thus continuing with self-care and obtaining favorable clinical results.

In this context, the Attention Model for Chronic Conditions aims to reorganize activities in Primary Health-Care (PHC) concerning people with chronic conditions ${ }^{(6)}$, adopting the supported self-care as one of its premises ${ }^{(6)}$. Its differential is the professional attitude, which tends to ensure favorable conditions for co-responsibility, resulting in a greater autonomy of the health service user. This can be implemented by elaborating a self-care plan based on specific goals and needs of individuals, which include assessment, counseling, agreement, assistance, and monitoring(6).

Nursing appointment guided by supported self-care orients practice of assistance through three main points: appropriate clinical management of the chronic disease; necessary changes in lifestyle; and appreciation of emotional aspects of patients, including changes in their vision of future, or in the way they handle and face chronic condition and its adversities ${ }^{(6)}$.

Such strategy has already proved to be effective to maintain the knowledge about the disease and its treatment ${ }^{(15)}$, although it still lacks studies that evaluate its effectiveness on individuals with DM2. With that in mind, the aim of this study is to verify the effect of nursing appointment on the cardiometabolic profile of people with DM2.

\section{METHOD}

\section{Ethical aspects}

Over the study development, all ethical recommendations regarding research with human beings have been followed. The project was approved by the Permanent Committee on Ethics in Research involving Human Beings, by the Brazilian Clinical Trials Registry and by the Universal Trial Number (UTN).

\section{Design, study location and period}

Randomized and controlled clinical trial, carried out from May 2014 to January 2015, in one of the six Basic Health Units (UBS - Unidade Básica de Saúde) belonging to a small town (less than 20,000 inhabitants) located in the North region of the State of Paraná - the one with the largest number of individuals with DM2 registered.

In this town, health service for people with DM within the $\mathrm{PHC}$ is not programmed, neither nursing appointments nor health education regular meetings are not performed. Assistance consists in carrying out medical appointments (by spontaneous demand), distribution of medicines (glyburide, metformin, and insulin) and supplies for application of insulin (syringes and needles), devices for glycemia monitoring (only for insulin-dependent individuals), and eventual lectures (usually once or twice a year), addressing hypertension and DM topics.

\section{Population and sample}

The population study covered 197 individuals with DM2 registered at the UBS. The inclusion criteria used were: DM2 diagnosis, age 40 or older, and be a town resident. On the other hand, the exclusion criteria were: presenting problems that 
would complicate or restrain verbal communication and/or going to the UBS. Regarding these criteria and the information provided by the health team, 27 individuals were excluded.

Sample size was calculated considering 170 eligible individuals, $1.9 \%$ standard deviation for $\mathrm{HbA} 1 \mathrm{c}$, as presented in another study ${ }^{(8)}, 1 \%$ minimum detectable difference, 0.05 significance level (a), 0.80 test statistical power, and $10 \%$ sample loss possibility, which resulted in a sample with 134 individuals.

All the 134 individuals who would participate in the study were randomly selected and then randomized into Intervention and Control groups, by using the R Project software. For being an open study, all people involved were aware of the intervention protocol.

In the control group, there were five losses during the study: three individuals passed away (due to a car accident, cancer and a stroke). One of them moved out of the city and another one refused to participate in the second evaluation. In the intervention group, there was no loss.

\section{Study protocol}

After forming two groups, the leading researcher visited the 134 participants, occasion when she invited them to participate in the study, clarified details on its development, conducted interview for sociodemographic, anthropometric and clinical data collection, and made a schedule to collect biochemical exams, which were carried out in the laboratory accredited by the municipality. For the participants in the intervention group, the first nursing appointment on UBS was also scheduled during home visits.

The anthropometric and clinical measurements verified before and after the intervention were: abdominal circumference $(A C)$, blood pressure (BP), weight and glomerular filtration rate (GFR). $A C$ and $B P$ were verified according to recommendation of the VI Brazilian Guidelines on Arterial Hypertension ${ }^{(16)}$. To measure weight, anthropometric scale was used, with capacity for 150 kilos. The tracking of the diabetic nephropathy represented by the GFR was performed by the Cockroft-Gault equation: WC $=(140-$ Age) $\times$ Weight $\times(0.8$ female) $/$ Plasmatic creatinine $\times 72$. The result classifies the GFR into normal ( $\geq 90$ ), discrete reduction of Glomerular Filtration Rate (GFR) (60 - 89), moderate reduction of GFR (30 - 59), severe reduction of GFR (15 $29)$, and kidney failure $(<15)^{(17)}$.

The leading researcher carried out the intervention from June to October 2014, which included three nursing appointments bimonthly, intercalated by two telephone calls. Nursing appointments had an average duration of 60 minutes and were carried out having the self-care support as referential. It is worth mentioning that, during the intervention period, the participants of both groups continued to receive the usual treatment at the UBS.

The professional performance during the intervention aimed at motivating/sensitizing people with DM2 about the clinical management of the disease, considering actions already carried out by them, necessary changes in lifestyle and emotional aspects that directly influence the glycemic control.
During the appointment, blood pressure and capillary glycemia were measured. Besides, perception of individuals was investigated regarding the chronic disease and major difficulties or problems related to changes in life habits, to keep it under control. After that, individuals were asked to choose one of these problems/difficulties and suggest some actions to get around them. From this point, a goal related to the problem chosen was established to be reached until the next appointment.

Identification of problems and establishment of actions/ goals so that individuals achieve them alone are some of the precepts of supported self-care, therefore, varying according to the need of each individual. Some of the main goals listed by participants were: weight loss, regular practice of physical activity, reduction of stress and of the continuous desire to eat something sweet.

On the next two appointments, when established goals were achieved, individuals were asked to choose another problem and indicate possible actions to solve it. Thus, a new goal was established to be added to the previous one. When not achieved, the initial goal was renegotiated based on difficulties experienced, motivation, willingness and interest of the individual. In such cases, a new goal has not been established.

It should be highlighted that, over the second appointment, the authors presented, discussed and delivered to the participants a folder they prepared containing information on eating habits (kinds of food recommended, allowed and to be avoided), acute complications, such as hypoglycemia and hyperglycemia (definition, symptoms, causes and indicated behaviors), major chronic complications (signs and symptoms), and care for disease control - importance of physical activity, care with feet and regular follow-up with health professionals. For insulin dependents, another folder was presented, discussed and delivered with information on storage, conservation and insulin transportation, proper use and disposal of syringes and needles, as well as care in the administration of insulin - application turn.

At the end of the third nursing appointment, participants received a request for new biochemical tests, with a collecting schedule after thirty days. On such occasion, the participants were informed that, within 30 to 45 days, a member of the research group would look for them at their residences to re-apply the questionnaires used in the beginning of the study.

The same nurse responsible for the nursing appointments made the telephone calls, aiming to follow the goal agreed during the appointment, know the expectations for the next appointment, solve doubts and assist participants on difficulties related to the agreed goal.

When an individual did not attend the nursing appointment on the scheduled day, a new appointment was booked to happen in a maximum period of 15 days. Regarding telephone contacts, up to three attempts were given, considering availability reported at the beginning of the study. At the end of the fifth month, those who passed through three nursing appointments and received two phone calls were 
considered done with the intervention, which corresponded to the total of participants.

Randomized individuals in the control group received the usual UBS follow-up and were evaluated during the beginning and six months after the study, with biochemical tests previously scheduled.

We highlighted that, after the second evaluation, in order to minimize differences in potential benefits offered to members of the intervention group, general guidelines about the disease and self-care were offered to members of this group, and the folders elaborated by the researchers were delivered to them.

Laboratory tests performed are the ones which integrate the follow-up routine of DM2 patients, according to the Brazilian Primary Care Notebook ${ }^{(17)}$ : plasmatic glycemia, $\mathrm{HbA1c}$, lipid profile, urea and creatinine. Two copies of the test results were printed, one given to the patient and the other filed in the UBS medical record after their values have been registered in a MS Excel spreadsheet for research purposes.

\section{Analysis of results and statistics}

The data was initially entered in Microsoft Office Excel 2010 spreadsheets and subsequently transferred to the IBM SPSS $^{\circledast}$ statistical program version 20 . At the beginning of the study, to verify whether the groups were homogeneous concerning the analyzed variables, the Pearson Chi-square test has been applied, which did not pointed out significant differences, an occurrence that enabled comparisons.

Afterwards, distribution of data through the KolmogorovSmirnov test was checked, which is carried out for independent and related samples. Then, we used the Student's t-test (for variables with normal distribution) to compare independent samples and the Mann-Whitney (for variables with abnormal distribution). In addition, for comparisons between related samples, we used the paired t-test (variables with normal distribution), and the Wilcoxon (variables with abnormal distribution). In all tests, the level of significance was established when $\mathrm{p} \leq 0.05$.

\section{RESULTS}

Most of the 134 participants were white $(80.9 \%)$, aged between 40 and $69(73.6 \%)$, had a spouse $(71.3 \%)$, were female $(68 \%)$, had an income up to two minimum wages $(57 \%)$ and had less than four years of education (54\%). We also identified that $47.1 \%$ had the disease diagnosis for more than 10 years and $22 \%$ already had complications.

Six months after the beginning of the study, when the two groups were compared, a statistically significant difference was evidenced regarding $\mathrm{HbA} 1 \mathrm{c}$ and systolic blood pressure, which were higher in the control group (Table 1).

Table 1 - Comparison of the cardiometabolic profile of people with Diabetes Mellitus type 2, in two moments of evaluation, Brazil, 2014-2015

\begin{tabular}{|c|c|c|c|c|c|c|c|c|}
\hline \multirow{3}{*}{ Variables } & \multicolumn{2}{|c|}{ Intervention Group } & \multirow[b]{3}{*}{$\mathbf{p}$} & \multicolumn{2}{|c|}{ Control Group } & \multirow[b]{3}{*}{$\mathbf{p}$} & \multicolumn{2}{|c|}{$\begin{array}{c}\text { Comparison of } \\
\text { independent samples }\end{array}$} \\
\hline & Before & After & & Before & After & & Before & After \\
\hline & $(n=67)$ & $(n=67)$ & & $(n=67)$ & $(n=62)$ & & $\mathbf{p}$ & $\mathbf{p}$ \\
\hline Glucose* $^{*}$ & 178.09 & 127.76 & $<\mathbf{0 . 0 0 1}^{+}$ & 167.7 & 132.84 & $<0.001^{+}$ & $0.446^{\ddagger}$ & $0.923^{\ddagger}$ \\
\hline Glycated hemoglobin* & 9.4 & 7.9 & $<0.001^{\dagger}$ & 9.1 & 8.9 & $0.081^{+}$ & $0.353^{\ddagger}$ & $0.006^{\ddagger}$ \\
\hline $\mathrm{LDL}^{\S / \mid}$ & 118.49 & 117.98 & $0.916^{\mathbb{1}}$ & 119.85 & 119.78 & $0.989^{\natural}$ & $0.918^{* *}$ & $0.269^{* *}$ \\
\hline HDL-C ${ }^{*++}$ & 45.19 & 45.28 & $0.932^{+}$ & 45.37 & 46.66 & $0.232^{+}$ & $0.926^{\ddagger}$ & $0.672^{\ddagger}$ \\
\hline Triglycerides ${ }^{*}$ & 131.37 & 165.3 & $0.012^{+}$ & 164.79 & 150.75 & $0.114^{+}$ & $0.197^{\ddagger}$ & $0.135^{\ddagger}$ \\
\hline Total cholesterol ॥ & 202.76 & 195.2 & $0.135^{\sharp}$ & 197.25 & 202.76 & $0.118^{\natural}$ & $0.495^{* *}$ & $0.244^{* *}$ \\
\hline Creatinine* & 1.05 & 1 & $0.011^{+}$ & 1.07 & 0.94 & $0.026^{+}$ & $0.346^{\ddagger}$ & $0.494^{\ddagger}$ \\
\hline Urea ${ }^{\prime \prime}$ & 39.91 & 38.7 & $0.514^{\pi}$ & 37.34 & 37.97 & $0.866^{\sharp}$ & $0.297^{* *}$ & $0.818^{* *}$ \\
\hline GFR $\| \neq \neq$ & 81 & 80 & $0.837^{\circledR}$ & 70 & 72 & $0.115^{\natural}$ & $0.143^{* *}$ & $0.424^{* *}$ \\
\hline Weight II & 77.19 & 75.5 & $<0.001^{9}$ & 78.24 & 80.53 & $<0.001^{9}$ & $0.855^{* *}$ & $0.056^{* *}$ \\
\hline Waist circumference ${ }^{\prime l}$ & 104.35 & 103.01 & $0.017^{\natural}$ & 105.3 & 107.7 & $<0.001^{\natural}$ & $0.883^{* *}$ & $0.058^{* *}$ \\
\hline Systolic Blood Pressure* & 140 & 131 & $0.003^{+}$ & 140 & 137 & $0.876^{+}$ & $0.387^{\ddagger}$ & $0.031^{\ddagger}$ \\
\hline Diastolic Blood Pressure* & 90 & 80 & $<0.001^{+}$ & 90 & 90 & $0.876^{+}$ & $0.668^{\ddagger}$ & $0.198^{\ddagger}$ \\
\hline
\end{tabular}

Note: * Variables with abnormal distribution; † Wilcoxon Test for related samples; $¥$ Mann-Whitney Test for independent samples; $§$ Low density lipoprotein; | Variable with normal distribution; I Paired T-test for related samples; ** T Test for independent samples; †† High-density lipoprotein; $¥ \ddagger$ Glomerular filtration rate. 
Furthermore, in the intergroup comparison, at different moments (initial and final), the participants of the intervention group presented positive changes for all variables, except triglycerides, while in the control group, most changes presented were negative, as there was an increase in means and medians of anthropometric (weight and AC) and biochemical (HDL, total cholesterol and GFR) variables.

Furthermore, it was shown that glucose and creatinine levels for both groups significantly reduced, although reduction was greater for those who participated in the intervention.

\section{DISCUSSION}

The nursing appointment based on supported self-care, associated with telephone monitoring, when compared with usual monitoring performed in the study scenario, presented a positive effect in relation to the $\mathrm{HbA} 1 \mathrm{c}$ variable and the systolic blood pressure. Results of meta-analysis performed through clinical trials showed that construction of shared care between professional and patient is a much more effective strategy to control glycemic levels and for the disease self-management, when compared with traditional strategies, guided only by professional orientations ${ }^{(18)}$.

The $1.5 \%$ average and significant reduction of $\mathrm{HbA} 1 \mathrm{c}$, presented by individuals of the intervention group, is consistent with results presented by meta-analysis of randomized studies used to evaluate the effectiveness of interventions in the disease management by individuals themselves ${ }^{(19)}$. Although the mean of $\mathrm{HbA} 1 \mathrm{c}$ for the intervention group has not evolved to indicative levels of good glycemic control, we highlight the consolidated fact in the literature, that for each $1 \%$ absolute reduction in the $\mathrm{HbA} 1 \mathrm{c}$ mean, there is a $37 \%$ reduction of risk of microvascular complications and a $32 \%$ reduction of risk of any complication related to $\mathrm{DM} 2^{(20)}$.

The fact of establishing concrete goals, based on the possibilities of participants and on plausible clinical results, in addition to allow patients to know more about parameters that indicate cardiometabolic control and to know better about possibilities of disease management, still favors engagement with self-care practices.

Body weight is an important factor to achieve glycemic control, in such a way that $5 \%$ to $10 \%$ of weight loss can significantly improve glycemic control and bring beneficial effects regarding other comorbidities ${ }^{(21)}$.

Significant reduction of weight (1.69 kg on average) and of AC evidenced among members of the intervention group is highlighted when we notice that in the control group, there was weight gain - $2.3 \mathrm{~kg}$ on average. This result corroborates the study about people with DM2 in Germany, in which guidelines related to healthy lifestyle were given for 12 weeks and significant weight reduction was verified only among members of the intervention group $(1.9 \mathrm{~kg})^{(22)}$.

In this study, the participants of the intervention group also showed a reduction not statistically significant of some laboratory parameters, such as LDL, total cholesterol, urea and glomerular filtration rate. However, such reductions are important from the clinical point of view, and may interfere in the disease prognosis. A reduction not significant of such parameters was also identified in a study that compared effectiveness between collective and individual interventions and showed improvement of clinical data for individual intervention participants ${ }^{(11)}$.

Finally, it was observed a reduction on pressure levels among participants of the intervention group, both in intergroup and intragroup comparisons. This result may have been influenced, as already observed in another study, by weight reduction $^{(21)}$, although it is not significant when compared with the control group. These results allow us to infer that participants of a monitoring program that stimulates self-care feel supported and motivated to implement some care, such as promoting change in life habits and greater adherence to the treatment, whether with or without medication.

Positive results observed from clinical and statistical point of view, probably are related to the use of supported self-care as a reference to conduct nursing appointment, as it allowed individuals to elect factors that, in their perceptions, needed changes with great emphasis on eating habits. In this sense, it is important to highlight that, in general, DM2 overweight patients, receive prescriptively general guidelines aimed at reducing food ingestion and about importance of regular practice of a physical activity, sometimes disregarding interest and availability of individuals to fulfill the goals established ${ }^{(23-24)}$.

This situation often happens due to limitations of professionals regarding their search for new perspectives for clinical practice and for recognition of bond importance and qualified listening during care, so that the proposed changes would have significance for the individuals ${ }^{(23)}$.

Thus, individualized support and guidance allow construction of change strategies that have meaning for individuals, which favors motivation to change behavior, similar to what has been identified in a study carried out in a health company in a municipality of Paraná, which pointed out a positive impact of individualized follow-up by a nurse focused on selfmanagement and disease control ${ }^{(13)}$.

Therefore, effective treatment of chronic diseases such as DM2, requires a new reading and readaptation of system and health care model, since people who get sick chronically demand regular and extensive contact during treatment, for their involvement and active participation in the process of identification problem and decision making ${ }^{(25)}$.

\section{Study limitations}

Despite the findings, some limitations can be pointed out, such as impossibility of attaching positive effect exclusively to the intervention, since this was carried out by a single professional, who may have specific interpersonal skills that favored the positive result accomplishment. Another limitation was the lack of monitoring on possible interactions between the participants of both groups.

\section{Study's implications and implications for practice}

Results found demonstrate that it is essential to think about assistance practice offered to people with DM2 on primary health care and evidence some needs such as: working with scheduled demand, with focus and incentive on self-care and on preparation of people for managing their own disease. 
These actions are important because the actual assistance model has not been able to reduce DM2 prevalence nor its complications.

In this context, the importance of this study stands out for nursing practice, since self-care and self-management of DM2 can be positively impacted by its actions. Therefore, we reaffirm the need for nurses to act as facilitators and promoters of the empowerment of individuals regarding the disease, enabling them to make decisions related to control and treatment and, this way, delay emergence of complications and have a better quality of life.

\section{CONCLUSION}

As a conclusion, nursing appointment based on supported self-care, associated with telephone monitoring, produced a significant reduction on $\mathrm{HbA} 1 \mathrm{c}$ levels and on systolic blood pressure.

Intervention strategies such as this one need to be planned and used by health teams, as they have low cost and can be associated with regular care and performed in the assistance for people with DM2. Focus on supported self-care can become an effective tool for the construction of a bond and a stimulus for the individual's autonomy. To do it so, it is necessary to invest on professional education, so that nurses can assist supported self-care, since it can improve assistance provided to people with DM2, favor their quality of life and qualify nurses' work.

\section{FUNDING}

CNPq - Conselho Nacional de Desenvolvimento Científico e Tecnológico (National Council for Scientific and Technological Development), process number 487109/2013-9.

\section{ERRATUM}

Article "Nursing appointment and cardiometabolic control of diabetics: a randomized clinical trial", with number of DOI: http://dx.doi. org/10.1590/0034-7167-2016-0352, published in the journal Revista Brasileira de Enfermagem, v70(3):468-7, on page 468:

Where it read:

\section{"Elen Ferraz Teston', Guilherme Oliveira de Arruda", Catarina Aparecida Sales", Sonia Silva Marcon"}

' Universidade Estadual do Paraná, Departamento de Enfermagem. Paranavaí-PR, Brasil.

" Universidade Estadual de Maringá, Programa de Pós-Graduação em Enfermagem. Maringá-PR, Brasil."

Read:

\section{"Elen Ferraz Teston', Guilherme Oliveira de Arruda", Catarina Aparecida Sales", Deise Serafim", Sonia Silva Marcon"}

\author{
' Universidade Estadual do Paraná, Nursing \\ Department. Paranavaí, Paraná, Brazil. \\ "Universidade Estadual de Maringá, \\ Postgraduate Program in Nursing. \\ Maringá, Paraná, Brazil."
}

\section{REFERENCES}

1. International Diabetes Federation: IDF Diabetes Atlas [Internet]. 7th edition. Brussels, Belgium: International Diabetes Federation; 2015 [cited 2015 Aug 10]. Available from: http://www.diabetesatlas.org/resources/2015-atlas.html

2. Isser BPM, Stopa SR, Chueiri PS, Szwarcwald CL, Malta DC, Monteiro HOC. Self-reported diabetes prevalence in Brazil: results from National Health Survey 2013. Epidemiol Serv Saúde [Internet]. 2015 [cited 2015 Aug 18];24(2):305-14. Available from: http://www.scielo.br/pdf/ress/v24n2/2237-9622-ress-24-02-00305.pdf

3. Malta DC, Moura L, Prado RR, Escalante JC, Schmidt MI, Duncan BB. Chronic non-communicable disease mortality in Brazil and its regions, 2000-2011. Epidemiol Serv Saúde [Internet]. 2014 [cited 2015 Aug 20];23(4):599-608. Available from: http://www. scielo.br/pdf/ress/v23n4/2237-9622-ress-23-04-00599.pdf

4. Ku GMV, Kegels G. Effects of the First Line Diabetes Care (FiLDCare) self-management education and support project on knowledge, attitudes, perceptions, self-management practices and glycaemic control: a quasi-experimental study conducted in the Northern Philippines. BMJ Open [Internet]. 2014 [cited 2015 Sep 1];4:1-13. Available from: http://bmjopen.bmj.com/content/4/8/e005317.full

5. Mendes KDS, Silveira RCCP, Galvão CM. Integrative literature review: a research method to incorporate evidence in health care and nursing. Texto Contexto Enferm [Internet]. 2008 [cited 2015 Sep 7];17(4):758-64. Available from: http://www.scielo.br/pdf/ tce/v17n4/18.pdf

6. Mendes EV. O cuidado das condições crônicas na atenção primária à saúde: o imperativo da consolidação da estratégia da saúde da família. Brasília: Organização Pan-Americana da Saúde; 2012 [cited 2015 Jun 10]. 512 p. Available from: http://bvsms.saude. gov.br/bvs/publicacoes/cuidado_condicoes_atencao_primaria_saude.pdf 
7. David GF, Torres HC, Reis IA. Attitude of health professionals in educational practices in Diabetes Mellitus in Primary. Cienc Cuid Saúde [Internet]. 2012 [cited 2015 Oct 12];11(4):758-66. Available from: http://www.periodicos.uem.br/ojs/index.php/ CiencCuidSaude/article/view/21658/pdf

8. Moreira RC, Mantovani MF, Soriano JV. Nursing Case Management and Glycemic Control Among Brazilians With Type 2 Diabetes: pragmatic clinical trial. Nurs Res [Internet]. 2015 [cited 2014 Jan 20]; 64(4):272-81. Available from: http://www.ncbi.nlm.nih.gov/ pubmed/26126062

9. Dobson R, Carter K, Cutfield R, Hulme A, Hulme R, McNamara C. Diabetes Text-Message Self-Management Support Program (SMS4BG): A Pilot Study. JMIR health [Internet]. 2015 [cited 2015 Oct 12];3(1):e32. Available from: http://www.ncbi.nlm.nih.gov/ pmc/articles/PMC4390615/

10. Dizaji MB, Taghdisi MH, Solhi M, Hoseini SM, Shafieyan Z, Qorbani M. Effects of educational intervention based on PRECEDE model on self care behaviors and control in patients with type 2 diabetes in 2012. J Diabetes Metabol Disorders [Internet]. 2014 [cited 2015 Nov 8];13:72. Available from: http://www.ncbi.nlm.nih.gov/pmc/articles/PMC4114427/

11. Vadstrup ES, Frolich A, Perrild H, Borg E, Roder M. Health-related quality of life and self-related health in patients with type 2 diabetes: Effects of group-based rehabilitation versus individual counselling. Health Qual Life Outcomes [Internet]. 2011 [cited 2015 Sep 6];9:110. Available from: http://hqlo.biomedcentral.com/articles/10.1186/1477-7525-9-110

12. Odnoletkova I, Goderis G, Nobels F, Aertgeerts B, Annemans L, Ramae D. Nurse-led telecoaching of people with type 2 diabetes in primary care: rationale, design and baseline data of a randomized controlled trial. BMC Fam Pract [Internet]. 2014 [cited 2015 Dec 12];15:24. Available from: http://bmcfampract.biomedcentral.com/articles/10.1186/1471-2296-15-24

13. Imazu MFM, Faria BN, Arruda GO, Sales CA, Marcon SS. Effectiveness of individual and group interventions for people with type 2 diabetes. Rev Latino-Am Enfermagem [Internet]. 2015 [cited 2016 Jan 12];23(2):200-07. Available from: http://www.ncbi.nlm. nih.gov/pmc/articles/PMC4458992/

14. Silva TFA, Rodrigues JEG, Silva APSM, Barros, MAR, Felipe GF, Machado ALG. Nursing consultation to persons with diabetes mellitus in primary care. REME Rev Min Enferm [Internet]. 2014 [cited 2016 Jan 7];18(3):710-6. Available from: https://www. researchgate.net/publication/280761746

15. Chagas IA, Camilo J, Santos MA, Rodrigues FFL, Arrelias CCA, Teixeira CRS, et al. Patients' knowledge of Diabetes five years after the end of an educational program. Rev Esc Enferm USP [Internet]. 2013 [cited 2016 Jan 27];47(5):1141-6. Available from: http:// www.scielo.br/pdf/ress/v23n4/2237-9622-ress-23-04-00599.pdf

16. Sociedade Brasileira de Cardiologia. IV Diretrizes Brasileira de Hipertensão. Arq Bras Cardiol [Internet]. 2010 [cited 2016 Feb 5];95(1sp):1-51. Available from: http://publicacoes.cardiol.br/consenso/2010/Diretriz_hipertensao_ERRATA.pdf

17. Brasil. Ministério da Saúde. Cadernos de Atenção Básica. Estratégias para o cuidado da pessoa com doença crônica. Diabetes Mellitus [Internet]. Brasília (DF): Ministério da Saúde; 2013 [cited 2016 Jan 5].160. Available from: http://bvsms.saude.gov.br/bvs/ publicacoes/estrategias_cuidado_pessoa_doenca_cronica_cab35.pdf

18. Tricco AC, Ivers NM, Grimshaw JM, Mohler, Turner L, Galipeau J, et al. Effectiveness of quality improvement strategies on the management of diabetes: a systematic review and meta-analysis. Lancet [Internet]. 2012 [cited 2016 Feb 12];379:2252-61. Available from: http://www.ncbi.nlm.nih.gov/pubmedhealth/PMH0046851/.

19. Pimouguet C, Le Goff M, Thiébaut R, Dartigues JF, Helmer C. Effectiveness of disease-management programs for improving diabetes care: a metaanalysis. CMAJ [Internet]. 2011 [cited 2016 Feb 18];183(2):115-27. Available from: http://www.ncbi.nlm. nih.gov/pmc/articles/PMC3033953/

20. United Kingdom Prospective Diabetes Study (UKPDS) Group. Intensive blood-glucose control with sulphonylureas or insulin compared with conventional treatment and risk of complications in patients with type 2 diabetes (UKPDS 33). Lancet [Internet]. 1998 [cited 2016 Feb 22];352(9131):837-53. Available from: http://www.ncbi.nlm.nih.gov/pubmed/9742976

21. Wing RR, Lang W, Wadden TA, Knowler WC, Bertoni AG, Hill JO et al. Benefits of modest weight loss in improving cardiovascular risk factors in overweight and obese individuals with type 2 diabetes. Diabetes Care [Internet]. 2011 [cited 2016 Mar 15];34:14816. Available from: http://www.ncbi.nlm.nih.gov/pmc/articles/PMC3120182/

22. Kempf K, Tankova T, Martin S. ROSSO-in-praxi-international: Long-Term Effects of Self-Monitoring of Blood Glucose on Glucometabolic Control in Patients with Type 2 Diabetes Mellitus Not Treated with Insulin. Diabetes Technol Therap [Internet]. 2013 [cited 2016 Mar 17];15(1):89-96. Available from: http://www.ncbi.nlm.nih.gov/pubmed/23194054

23. Santos AL, Marcon SS. How people with diabetes evaluate participation of their family in their health care. Invest Educ Enferm [Internet]. 2014 [cited 2016 Mar 17];32(2):260-9. Available from: http://www.scielo.org.co/pdf/iee/v32n2/v32n2a09.pdf

24. Duncan BB, Chor D, Aquino EML, Bensenor IM, Mill JG, Schmidt MI, et al. [Chronic Non-Communicable Diseases in Brazil: priorities for disease management and research]. Rev Saúde Pública [Internet]. 2012 [cited 2016 Mar 21];46(1):126-34. Available from: http://www.scielo.br/pdf/rsp/v46s1/17.pdf Portuguese.

25. Mash B, Levitt N, Stevyn K, Zwarenstein M, Rollnick S. Effectiveness of a group diabetes education programme in underserved communities in South Africa: pragmatic cluster randomized control trial. BMC Fam Pract [Internet]. 2012 [cited 2016 Apr 01];13:126. Available from: http://bmcfampract.biomedcentral.com/articles/10.1186/1471-2296-13-126 